\title{
ANTIBIOCORROSIVE HYBRID MATERIALS WITH HIGH DURABILITY
}

\author{
Khatuna Barbakadze 1, 2, 3, Witold Brostow ${ }^{3}{ }^{凶}$, Nathalie Hnatchuk $^{3}$, Giorgi Lekishvili ${ }^{1}$, \\ Badri Arziani ${ }^{1}$, Krzysztof Zagórski ${ }^{4}$, Nodar Lekishvili ${ }^{2}$
}

https://doi.org/10.23939/chcht15.04.500

\begin{abstract}
We have developed novel antibiocorrosive multifunctional hybrid materials based on functionalized perfluoroalkyl methacrylate copolymers with epoxy groups in main chains and selected biologically active compounds. The hybrids are transparent, show good adhesion to various surfaces (plastic, wood), high viscoelastic recovery in scratch testing, low wear rates and glass transitions above $323 \mathrm{~K}$. No phase separation is seen in scanning electron micrography. Enhanced mechanical strength and good abrasion resistance are advantages for uses of our protective and antibiocorrosive coatings in various applications including protection of cultural heritage.
\end{abstract}

Keywords: hybrid materials, protective coatings, antibiocorrosive coatings, perfluoroalkyl methacrylates.

\section{Introduction}

Microbial pollutants cause damage to natural and synthetic polymeric materials and wares as well as to objects of cultural heritage and to ecosystem. This situation behooves us to develop materials and methods that can effectively prevent and/or inhibit the growth of detrimental microorganisms and to control biocorrosion processes [1,2].

\footnotetext{
${ }^{1}$ Department of Medical Chemistry, Faculty of Pharmacy, Tbilisi Medical University,

33 Vazha Pshavela Ave., Tbilisi 0186, Georgia

${ }_{2}^{2}$ Institute of Inorganic-Organic Hybrid Compounds and Nontraditional Materials,

Faculty of Exact and Natural Sciences, Ivane Javahishvili University, 3 Ilia Chavchavadze Ave., Tbilisi 0179, Georgia

${ }^{3}$ Laboratory of Advanced Polymers \& Optimized Materials (LAPOM), Department of Materials Science and Engineering and Department of Physics, University of North Texas,

3940 North Elm Street, Denton TX 76207, USA

${ }^{4}$ College of Mechanics and Robotics, AGH University of Science and Technology,

30 Adama Mickiewicza Aleja, Krakow 30-059, Poland

wkbrostow@gmail.com

(C) Barbakadze K., Brostow W., Hnatchuk N., Lekishvili G., Arziani B., Zagórski K., Lekishvili N., 2021
}

During the last two decades, design of the polyfunctional hybrid materials has attracted considerable research interest. The wide range of possible hybrids may include innovative combinations, starting from organic and organometallic molecules to biomolecules, inorganic clusters, fullerenes or nano- and submicro sized particles dispersed in polymer matrix. Functionalized polymeric hybrids with a variety of structures have a wide range of applications including antimicrobial polymer composites, adhesives, dye composites, optical materials, membranes, biomedical materials, coatings, and more [3-5]. Polyfunctional polymers with linear macrochains and regular structure, containing $\mathrm{Si}-\mathrm{N}-, \mathrm{Si}-\mathrm{O}$ and $\mathrm{NH}$ groups can be used to obtain bioactive composites with specific properties including important antibiocorrosion capability [6, 7]. Among them are polyfunctional heterochain organic polymers (polyurethane elastomers, polyurethane-acrylates, polyurethane ionomers and more), carbofunctional siliconorganic and other polyfunctional heterochain polymers [8].

Fluorinated polymers and copolymers display high thermal stability, satisfactory mechanical properties at high temperatures, resistance to oxidation and hydrolytic decompositions, weatherability, low flammability, inertness to solvents (hydrocarbons, acids, and alkalis), low dielectric constants and low surface energies [9-15]. Due to such unique combination of advantageous properties, fluoropolymers are widely used in architectural, optoelectronic, automotive, aerospace, and aeronautic industries, microelectronics, and chemical engineering as well as in medicine, such as dental materials and artificial joints. The low refractive index and high optical transparency make amorphous perfluoropolymers a promising candidate for applications in high-performance protecting coatings, surface modifiers, and optical materials or shatter-resistant alternative to glass $[10,16,17]$.

Despite such unique properties of fluorine-organic polymers, they have worse adhesion properties than epoxy-based polymeric matrices and coatings.

Abovementioned considerations led to the creation of our program of work. The main objective of our work was to choose relatively easily available perfluoroalkyl methacrylates $\left(\mathrm{F}_{\mathrm{n}} \mathrm{MA}\right)$ with good reactivity as initial 
monomers for synthesis of hydrophobic and mechanically stable fluorine-organic polymers. By copolymerization of selected perfluoroalkyl methacrylates with allyl glycidyl ether (epoxy allyl monomer) containing adhesive functional groups makes it possible to functionalize transparent fluorine-organic methacrylates by incorporation of easily hardened epoxy groups in their macro chain.

The most novel aspect of the presented work is the development of easily curable polymer matrices for antimicrobial coatings based on fluorine-organic methacrylates with an epoxy group and regular structure instead of the previously used by us polyepoxides [18] which are used as blends modified by silicon-organic oligomers which complicates the reproducibility of the properties of resulting materials and makes the composition more expensive.

\section{Experimental}

\subsection{Synthesis}

Despite the unique properties of fluoropolymers, they are characterized by worse adhesion properties compared to other polymers such as polyurethanes or polyepoxides used in antibiocorrosive matrices [18, 19]. This factor had to be kept in mind in our synthesis.

New hydrophobic and mechanically stable fluorineorganic polymers were obtained by means of targeted functionalization of polyperfluoroalkyl methacrylates $\left(F_{n} M A s\right)$. Radical copolymerization of selected fluorine containing monomers with allyl glycidyl ether was carried out to obtain copolymers with fluoroalkyl- and epoxy side groups in their main chain (Scheme 1):

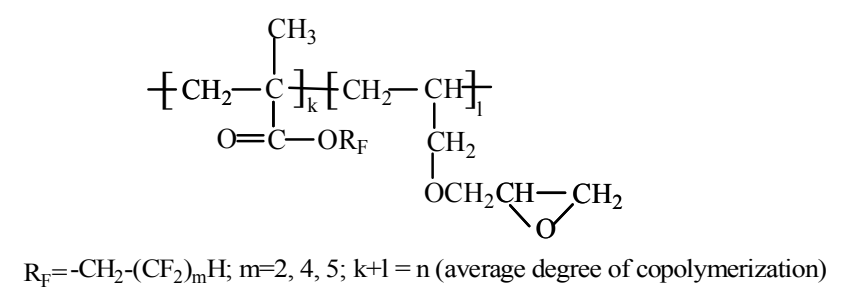

Scheme 1. Functionalized polyperfluoroalkyl methacrylates

Based on preliminary investigations, co-monomers with the molar ratios of $1: 1$ and 7:3 were chosen. The reaction was carried out in a polydimethylsiloxane (PMS100) oil bath in the presence of $1 \mathrm{wt} \%$ of benzoyl peroxide (BPO, initiator). The mixture was heated to $343-$ $358 \mathrm{~K}$ in dry argon area during $4-5 \mathrm{~h}$, in each case until formation of a highly viscous transparent mass - a solution of copolymers in the corresponding monomers.

The obtained copolymers were isolated from reaction mixture by heptane from an ethyl acetate solu- tion. The yield of copolymers was $70-80 \%$. The specific viscosity $\left(\eta_{s}\right)$ of the copolymers determined in the capillary viscosimeter in $1 \%$ ethyl acetate solution was in the range of $0.15-0.38 \mathrm{dL} / \mathrm{g}$. 1,1,3-Trihydrotetrafluoropropyl methacrylate $\left(\mathrm{F}_{4} \mathrm{MA}\right)$ formed solid, rigid products; copolymers based on 1,1,5-trihydrooctafluoropropyl methacrylate $\left(\mathrm{F}_{8} \mathrm{MA}\right)$ and 1,1,7-trihydrododecafluoropropyl methacrylate $\left(\mathrm{F}_{12} \mathrm{MA}\right)$ formed elastic transparent solid products.

The formation of comparatively low molecular weight copolymers should be associated with the degradative effect of radical mechanism of copolymerization caused by high mobility of $\mathrm{C}-\mathrm{H}$ groups bonded to the allyl monomer's oxygen [20]. By determination of the epoxy numbers, it was established that the content of allyl glycidyl ether rings in the copolymers was less than $20 \mathrm{~mol} \%$.

Fourier transform infrared spectroscopy (FTIR) was performed with a Perkin Elmer FT-IR Spectrum BX $11\left(350-4000 \mathrm{~cm}^{-1}\right)$ spectrophotometer in $\mathrm{KBr}$ monocrystal. In the infrared spectra weak absorption bands characteristic of the epoxy group are shown at 830, 915925 and $1245-1262 \mathrm{~cm}^{-1}$. Absorption band for ester carbonyl group appears at $1739-1750 \mathrm{~cm}^{-1}$ and for carbonyl $(\mathrm{C}=\mathrm{O})$ groups at $1633-1665 \mathrm{~cm}^{-1}$. The bands at $3000-3002$ and $1370-1410 \mathrm{~cm}^{-1}$ are attributed to the alkyl $\left(\mathrm{CH}_{3}\right)$ groups and the $\mathrm{CH}_{2}, \mathrm{C}-\mathrm{H}$ and $\mathrm{C}-\mathrm{F}$ bands appear at 2905-2910 and 1070-1230 $\mathrm{cm}^{-1}$.

As bioactive component we chose $\alpha$-ferrocenylethyl-4-methoxy-2-nitrophenylamine, $\alpha$-ferrocenylethyl-4-(1-adamantoyl)-2-nitrophenylamine] and heterometal coordination compounds containing organometallic $\left[\operatorname{bis}\left(\eta^{5}\right.\right.$-cyclopentadienyl $)$ iron] and polycarbocyclic fragments (tricyclo-[3.3.1.1 $\left.1^{3,7}\right]$-decane) $[18,21]$ (Table 1, Scheme 2). Sadym and coworkers have developed a measure of antimicrobial activity which they called "Pa" [16]. To avoid confusion with the Pascal unit, we shall use the term "Aa" for antibacterial activity they defined. Aa against influenza, picornavirus, adenovirus and poxvirus) is in the range of $\mathrm{Aa} \approx 0.601-0.778$. For antiparasitic activity against coccidial, histomonas and nematodes we have the of range $\mathrm{Aa} \approx 0.536-0.689$. For antimycobacterial activity we have $\mathrm{Aa} \approx 0.549-0.599$. Apparently for Aa $>0.5$ "the given compound will most likely exhibit this activity in experiment" [22].

Taking into account the accessibility and diversity of polymeric and bioactive components for the design of targeted materials, one finds a great opportunity for varying of combinations; during their creation, the main idea is to achieve prolonged maintenance of their appearance and improvement of tribological, mechanical and other operational characteristics.

Antimicrobial hybrid materials were prepared by adding of $3 \mathrm{wt} \%$ of selected bioactive compounds (BC) 
into the obtained functionalized polyperfluoroalkyl methacrylates ( $\left.\mathrm{F}_{\mathrm{n}} \mathrm{MA}-\mathrm{AGE} / 1: 1,7: 3\right)$. The components were stirred for $30-40 \mathrm{~min}(343 \mathrm{~K})$, then hexamethylenediamine (HMDA; 5, 7, $10 \mathrm{wt} \%$ ) was used

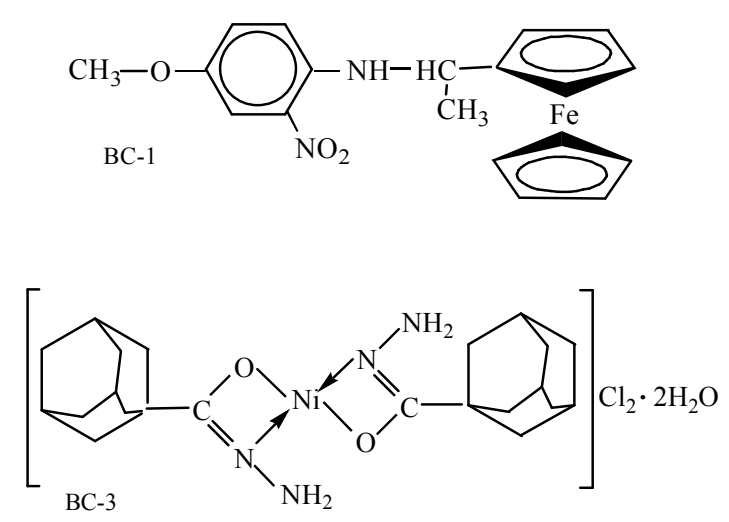

as a curing agent. The resulting light-colored homogenous composites were deposited on the surfaces of various materials and kept for 3-5 days at room temperature.

The materials so obtained are listed in Table 1.

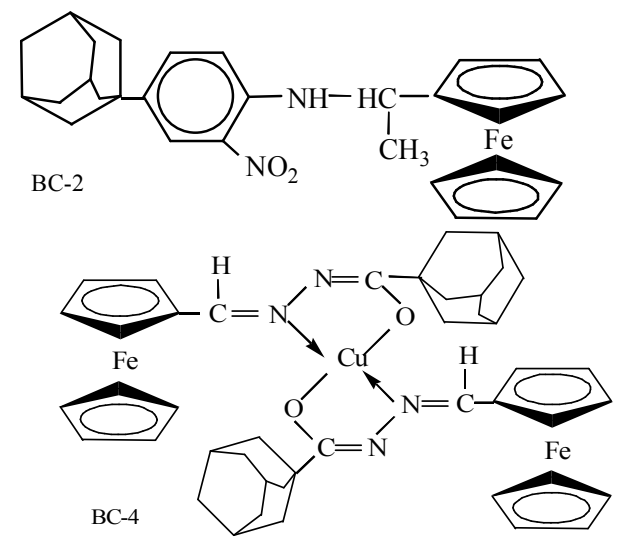

Scheme 2. Bioactive hybrid components based on organometallic and polycarbocyclic fragments

Table 1

Antimicrobial composites based on copolymers with fluoroalkyl and epoxy side groups

\begin{tabular}{|c|c|c|c|}
\hline Number & Composite & Number & Composite \\
\hline I & $\mathrm{F}_{4} \mathrm{MA}-\mathrm{AGE}(1: 1) / 5 \%$ HMDA & XVIII & $\mathrm{F}_{8} \mathrm{MA}-\mathrm{AGE}(1: 1) / 3 \%$ BC-3 / 7\% HMDA \\
\hline II & $\mathrm{F}_{4} \mathrm{MA}-\mathrm{AGE}(1: 1) / 3 \% \mathrm{BC}-1 / 5 \%$ HMDA & XIX & $\mathrm{F}_{8} \mathrm{MA}-\mathrm{AGE}(1: 1) / 3 \%$ BC-4 / 7\% HMDA \\
\hline III & $\mathrm{F}_{4} \mathrm{MA}-\mathrm{AGE}(1: 1) / 3 \% \mathrm{BC}-2 / 5 \% \mathrm{HMDA}$ & $\mathrm{XX}$ & $\mathrm{F}_{8} \mathrm{MA}-\mathrm{AGE}(1: 1) / 10 \% \mathrm{HMDA}$ \\
\hline IV & $\mathrm{F}_{4} \mathrm{MA}-\mathrm{AGE}(1: 1) / 3 \% \mathrm{BC}-3 / 5 \%$ HMDA & XXI & $\mathrm{F}_{8} \mathrm{MA}-\mathrm{AGE}(1: 1) / 3 \%$ BC-3 / 10\% HMDA \\
\hline $\mathrm{V}$ & $\mathrm{F}_{4} \mathrm{MA}-\mathrm{AGE}(1: 1) / 3 \%$ BC-4 / 5\% HMDA & XXII & $\mathrm{F}_{8} \mathrm{MA}-\mathrm{AGE}(7: 3) / 7 \%$ HMDA \\
\hline VI & $\mathrm{F}_{4} \mathrm{MA}-\mathrm{AGE}(1: 1) / 7 \%$ HMDA & XXIII & $\mathrm{F}_{8} \mathrm{MA}-\mathrm{AGE}(7: 3) / 3 \%$ BC-1 / 7\% HMDA \\
\hline VII & $\mathrm{F}_{4} \mathrm{MA}-\mathrm{AGE}(1: 1) / 3 \% \mathrm{BC}-1 / 7 \%$ HMDA & XXIV & F $F_{8}$ MA-AGE (7:3) / 3\% BC-2 / 7\% HMDA \\
\hline VIII & $\mathrm{F}_{4} \mathrm{MA}-\mathrm{AGE}(1: 1) / 3 \%$ BC-3 / 7\% HMDA & XXV & F MA-AGE (7:3) / 3\% BC-3 / 7\% HMDA \\
\hline IX & $\mathrm{F}_{4} \mathrm{MA}-\mathrm{AGE}(1: 1) / 10 \%$ HMDA & XXVI & 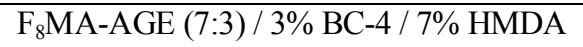 \\
\hline $\mathrm{X}$ & $\mathrm{F}_{4} \mathrm{MA}-\mathrm{AGE}(1: 1) / 3 \%$ BC-3 / 10\% HMDA & XXVII & $\mathrm{F}_{8} \mathrm{MA}-\mathrm{AGE}(7: 3) / 10 \%$ HMDA \\
\hline $\mathrm{XI}$ & $\mathrm{F}_{4} \mathrm{MA}-\mathrm{AGE}(7: 3) / 7 \%$ HMDA & XXVIII & F8A-AGE (7:3) / 3\% BC-3 / 10\% HMDA \\
\hline XII & $\mathrm{F}_{4} \mathrm{MA}-\mathrm{AGE}(7: 3) / 3 \%$ BC-3 / 7\% HMDA & XXIX & $\mathrm{F}_{12} \mathrm{MA}-\mathrm{AGE}(1: 1) / 7 \%$ HMDA \\
\hline XIII & $\mathrm{F}_{4} \mathrm{MA}-\mathrm{AGE}(7: 3) / 10 \%$ HMDA & $\mathrm{XXX}$ & $\mathrm{F}_{12} \mathrm{MA}-\mathrm{AGE}(1: 1) / 3 \% \mathrm{BC}-1 / 7 \%$ HMDA \\
\hline XIV & $\mathrm{F}_{4} \mathrm{MA}-\mathrm{AGE}(7: 3) / 3 \%$ BC-3 / 10\% HMDA & XXXI & $\mathrm{F}_{12} \mathrm{MA}-\mathrm{AGE}(1: 1) / 3 \% \mathrm{BC}-2 / 7 \%$ HMDA \\
\hline $\mathrm{XV}$ & $\mathrm{F}_{8} \mathrm{MA}-\mathrm{AGE}(1: 1) / 7 \%$ HMDA & XXXII & $\mathrm{F}_{12} \mathrm{MA}-\mathrm{AGE}(1: 1) / 3 \%$ BC-3 / 7\% HMDA \\
\hline XVI & $\mathrm{F}_{8} \mathrm{MA}-\mathrm{AGE}(1: 1) / 3 \% \mathrm{BC}-1 / 7 \%$ HMDA & XXXIII & $\mathrm{F}_{12} \mathrm{MA}-\mathrm{AGE}(1: 1) / 3 \%$ BC-4 / 7\% HMDA \\
\hline XVII & $\mathrm{F}_{8} \mathrm{MA}-\mathrm{AGE}(1: 1) / 3 \% \mathrm{BC}-2 / 7 \%$ HMDA & & \\
\hline
\end{tabular}

\subsection{Thermophysical Characterization}

Thermophysical properties of our hybrid samples were studied with differential scanning calorimetry (DSC) and thermogravimetry (TGA). DSC tests were performed with a differential scanning calorimeter from Netzsch, Selb, Germany, model DSC 200, to locate the phase transitions. Testing conditions were as follows: temperature range from 173 up to $573 \mathrm{~K}$ and heating rate of $5 \mathrm{~K} / \mathrm{min}$ in dry $\mathrm{N}_{2}$ atmosphere. Samples of about $10 \mathrm{mg}$ each were enclosed in aluminium DSC capsules.

Perkin Elmer TGA7 apparatus was used in order to evaluate thermal stability and degradation behavior of each sample. Tests were conducted under dry $\mathrm{N}_{2}$ atmosphere in the temperature range of $323-1073 \mathrm{~K}$ and at the heating rate of $10 \mathrm{~K} / \mathrm{min}$. Both DSC and TGA techniques are well explained by Menard [23]. DSC monitors heat effects associated with phase transitions and chemical reactions as a function of temperature and is used to characterize properties such as the crystallinity, thermal transitions and the melting temperatures.

\subsection{Scratch Resistance Testing}

Scratch and adhesion tests were performed using a Micro-Scratch Tester (MST) from CSM, Peseux, Neucha- 
tel, Switzerland, utilizing the CSEM Scratch Software Version 2.3; one applies a constantly increasing force from 0 to $30.0 \mathrm{~N}$ to the samples or else a constant force.

The sliding wear determination (SWD) was performed by multiple scratching with a diamond tip along the same groove [24, 25]. Two parameters are obtained in the determination of scratch resistance: penetration (instantaneous) depth $R_{p}$ and residual (healing) depth $R_{h}$ determined two minutes later. The viscoelastic recovery $(\varphi, \%)$ is defined as:

$$
\varphi=\left[\left(R_{p}-R_{h}\right) / R_{p}\right] \cdot 100
$$

Progressive scratch testing was performed with the following parameters: initial load $0.03 \mathrm{~N}$, final load $30.0 \mathrm{~N}$, loading rate $30.0 \mathrm{~N} / \mathrm{min}$, scanning load $0.03 \mathrm{~N}$, scratch length $8.0 \mathrm{~mm}$ and scratch speed $5.9 \mathrm{~mm} / \mathrm{min}$. SWD tests were performed under a constant load of $5.0 \mathrm{~N}$ with the scratch length $5.0 \mathrm{~mm}$. For each sample 10 scratch runs were performed, at the scratch velocity $10.0 \mathrm{~mm} / \mathrm{min}$ at room temperature $(293 \pm 2 \mathrm{~K})$. The conical diamond intender with $200 \mu \mathrm{m}$ diameter and the cone angle of $120^{\circ}$ was used.

\subsection{Dynamic Friction}

Dynamic friction $\lambda$ was determined by sliding using a Nanovea pin-on-disk tribometer from Micro Photonics Inc. 440 steel balls made by Salem Speciality Balls with the diameter of $3.2 \mathrm{~mm}$ were used. The tests were performed under the following conditions: temperature $293 \pm 2 \mathrm{~K}$, speed $100 \mathrm{rpm}$, sliding distance $40 \mathrm{~m}$, radius $2.0 \mathrm{~mm}$, load $5.0 \mathrm{~N}$, number of revolutions 2000, and test duration $20 \mathrm{~min}$. The friction is defined as:

$$
\lambda=f / F_{n}
$$

where $f$ is the friction force in Newtons; $F_{n}$ is the normal force.

\section{Results and Discussion}

\subsection{Thermophysical Characterization}

Our DSC results show that all our materials are amorphous. Melting transitions are not visible and exothermic peaks characteristic of crystallization are not displayed. Kalogeras and Hagg Lobland note that the glass transitions regions are usually broad [26]. There is a habit of representing those regions by a single number called the glass transition temperatures of tested samples $\left(T_{g}\right)$ and there are various ways defining that temperature. We have taken the values of $T_{g}$ as the middle points of the falls of the DSC curves. All hybrids have $T_{g}$ points in the region of $323 \mathrm{~K}$ to $338 \mathrm{~K}$, which is important for the applications of our coatings. DSC diagrams show also phase transitions in the glassy state - so called $\alpha$ transitions - centered in the range from $240 \mathrm{~K}$ to $230 \mathrm{~K}$ (Table 2). Addition of bioactive compounds enhances the stability of the low temperature amorphous phase.

TGA was used to evaluate thermal degradation behavior of our hybrids. Thermal stability parameters: temperature of destruction $\left(T_{d e s}\right)$, weight loss (\%) and the temperature of maximum rate of degradation $\left(T_{\max }\right.$; temperature after no changes are observed) are displayed in Table 3.

We see that polymer composites and antimicrobial hybrid materials, containing fluoroalkyl- and epoxy side groups obtained by radical copolymerization of 1,1,3trihydrotetrafluoropropyl methacrylate with AGE, are stable up to $693 \mathrm{~K}$; the respective weight loss in the range of $693-728 \mathrm{~K}$ is $25-37 \%$ (Table 2, I-XIV).

As also seen in Table 2, increasing the fluoroalkyl chain length improves the resistance to thermal degradation of the hybrids. Our materials containing fluoroalkyl- and epoxy side groups obtained by radical copolymerization of 1,1,5-trihydrooctafluoropropyl methacrylate with AGE ( $\mathrm{F}_{8} \mathrm{MA}-\mathrm{AGE}$ ) are stable up to $713 \mathrm{~K}$ and weight loss in the range of $713-728 \mathrm{~K}$ consists of $18-30 \%$ (Table 2, XV-XXVIII). The hybrids based on 1,1,7-trihydrododecafluoropropyl methacrylate $\left(\mathrm{F}_{12} \mathrm{MA}-\mathrm{AGE}\right)$ are stable up to $703 \mathrm{KC}$ and weight loss in the range of 705$710 \mathrm{~K}$ consists of $29-37 \%$ (Table 2, XXIX-XXXVII).

We infer that modification increases the thermal stability of our materials and weight loss is shifted to higher temperatures; these effects are enhanced further by addition of bioactive component and by increasing the curing agent content.

Table 2

$T_{g} / T_{a}$ values obtained for some hybrid materials containing perfluoroalkyl methacrylic and epoxy side groups

\begin{tabular}{|c|c|c|c|c|c|}
\hline Hybrid & $T_{g} / T_{a}, \mathrm{~K}$ & Hybrid & $T_{g} / T_{\alpha}, \mathrm{K}$ & Hybrid & $T_{g} / T_{a}, \mathrm{~K}$ \\
\hline I & $337.7 / 230.6$ & VIII & $329.0 / 238.5$ & XVIII & $327.1 / 241.1$ \\
\hline II & $333.3 / 232.5$ & X & $332.7 / 237.2$ & XXV & $325.5 / 239.8$ \\
\hline IV & $334.7 / 230.4$ & XII & $331.7 / 234.1$ & XXVIII & $327.4 / 237.6$ \\
\hline VII & $335.6 / 233.5$ & XVI & $328.2 / 239.4$ & XXXIII & $328.0 / 230.7$ \\
\hline
\end{tabular}


TGA data for polymer composites and antimicrobial hybrid materials containing perfluoroalkyl methacrylic and epoxy side groups

\begin{tabular}{|c|c|c|c|c|c|c|c|}
\hline $\begin{array}{c}\text { Hybrid } \\
\text { composite }\end{array}$ & $\mathrm{T}_{\text {des., }}{ }^{0} \mathrm{C}$ & Weight loss, $\%$ & $\mathrm{~T}_{\max },{ }^{0} \mathrm{C}$ & $\begin{array}{c}\text { Hybrid } \\
\text { composite }\end{array}$ & $\mathrm{T}_{\text {des. }}{ }^{0} \mathrm{C}$ & Weight loss, $\%$ & $\mathrm{~T}_{\max },{ }^{0} \mathrm{C}$ \\
\hline I & 438 & 25 & 440 & XVIII & 439 & 27 & 440 \\
\hline II & 433 & 37 & 435 & XIX & 432 & 29 & 435 \\
\hline III & 440 & 34 & 445 & XX & 446 & 27 & 450 \\
\hline IV & 440 & 24 & 445 & XXI & 441 & 17 & 445 \\
\hline V & 428 & 37 & 430 & XXII & 435 & 30 & 440 \\
\hline VI & 441 & 30 & 445 & XXIV & 446 & 30 & 450 \\
\hline VII & 445 & 34 & 448 & XXV & 434 & 26 & 440 \\
\hline VIII & 443 & 26 & 445 & XXVII & 453 & 26 & 455 \\
\hline IX & 453 & 28 & 455 & XXVIII & 436 & 26 & 440 \\
\hline X & 453 & 33 & 455 & XXIX & 432 & 37 & 435 \\
\hline XI & 434 & 31 & 435 & XXX & 435 & 32 & 439 \\
\hline XIII & 442 & 26 & 445 & XXXI & 436 & 28 & 440 \\
\hline XIV & 418 & 33 & 420 & XXXII & 434 & 24 & 435 \\
\hline XV & 439 & 28 & 440 & XXXIII & 437 & 31 & 440 \\
\hline
\end{tabular}

\subsection{Scratch Resistance Testing}

Results of SWD are shown in Fig. 1 (penetration depths) and Fig. 2 (residual depths). Tribological properties of composites based on main polymer matrices were examined as a reference.

As one can see in Fig. 1, modification improves resistance of composites to instantaneous deformation by micro scratching. At the applied load, hybrid composites based on $\mathrm{F}_{4} \mathrm{MA}-\mathrm{AGE}=1: 1$ (Fig. 1; II, III, V) have the original penetration depth in the range $98-110 \mu \mathrm{m}$ while $R_{p} \approx 123 \mu \mathrm{m}$ for the basic polymer matrix. The increase of curing agent (HMDA) concentration from 5 to 7 and then to $10 \mathrm{wt} \%$ also causes improvement of penetration depth values of the basic polymer matrix on the average from 123 to 64 and to $59 \mu \mathrm{m}$, respectively (Fig. 1d; I, VI, IX).

Looking for the best material, we see that the maximum decrease of $R_{p}$ value and the best resistance to instantaneous deformation is seen in the polymer matrix $\mathrm{F}_{4} \mathrm{MA}-\mathrm{AGE}$ 1:1/10 wt\% HMDA and the hybrid composite based on it (Fig. 1; IX-X).

Diagrams of the penetration depths for materials based on $\mathrm{F}_{8} \mathrm{MA}$ (Fig. 1; XV-XXI) also show improvement of resistance to instantaneous deformation (Fig. 1; XV, $\mathrm{XX}$ ) along with increasing concentration of the curing agent (HMDA) from 7 to $10 \mathrm{wt} \%$.

The increase of molar ratio of 1,1,3trihydrotetrafluoropropyl methacrylate in the copolymer $\left(\mathrm{F}_{4} \mathrm{MA}-\mathrm{AGE}=7: 3\right)$ is counterproductive for our purposes since we get larger values of the penetration depth (Fig. 1; XIII-XIV) comparatively to the matrices with a similar composition (Fig. 1; IX-X). Nevertheless, comparison of composites - $\mathrm{F}_{4} \mathrm{MA}-\mathrm{AGE}$ 1:1/5 wt $\%$ HMDA and $\mathrm{F}_{4} \mathrm{MA}-$ AGE $7: 3 / 10 \mathrm{wt} \%$ HMDA show better resistance to instantaneous deformation by micro scratching for the latter one (Fig. 1; I, XIII).

In all cases, as it was expected, one observes typically a slight increase (on the average by $10-25 \mu \mathrm{m}$ ) of penetration depth by incorporation of $\mathrm{BCs}$ in polymer matrices. These effects can be explained by the spatial structures of BCs used (Fig. 1; VII, VIII, X, XIV; XVIXIX, XXI).

Among the basic polymer matrices obtained based on $\mathrm{F}_{4} \mathrm{MA}$ and $\mathrm{F}_{8} \mathrm{MA}$, the largest reduction in $R_{p}$ displays the composite $\mathrm{F}_{4} \mathrm{MA}-\mathrm{AGE}$ 1:1/10 wt\% HMDA (Fig. 1; IX). Comparison of testing results of hybrids with similar compositions shows shallow $R_{p}$ values for matrices based on fluoromethacrylic copolymers with short fluoroalkyl chains (Fig. 1; XI, XV, XIII, XX, respectively).

Fig. 2 shows the residual (after healing) depth $\left(R_{h}\right)$ diagrams for our composites at a constant load $(5.0 \mathrm{~N})$ as a function of the scratch test number. Residual depth of hybrids based on $\mathrm{F}_{4} \mathrm{MA}$ largely decreases (Fig. 2; II, III, V). After some initial increases of $R_{h}$ with the increasing test number, asymptotic behavior is seen; further runs provide hardly any change. The increase of concentration of the curing agent (HMDA) lowers residual depth of the basic polymer matrix ( $\left.\mathrm{F}_{4} \mathrm{MA}-\mathrm{AGE} 1: 1\right)$ from 71 to 43 and $30 \mu \mathrm{m}$, respectively (Fig. 2; I, VI, IX). Incorporation of BCs into composites causes an insignificant decrease of $R_{h}$, on the average by $8-15 \mu \mathrm{m}$ (Fig. 2; VII, VIII, X). The largest reduction of $R_{h}$ is obtained by increasing the molar ratio of copolymers, namely for $\mathrm{F}_{4} \mathrm{MA}-\mathrm{AGE}=7: 3$ (Fig. 2; XIII). 


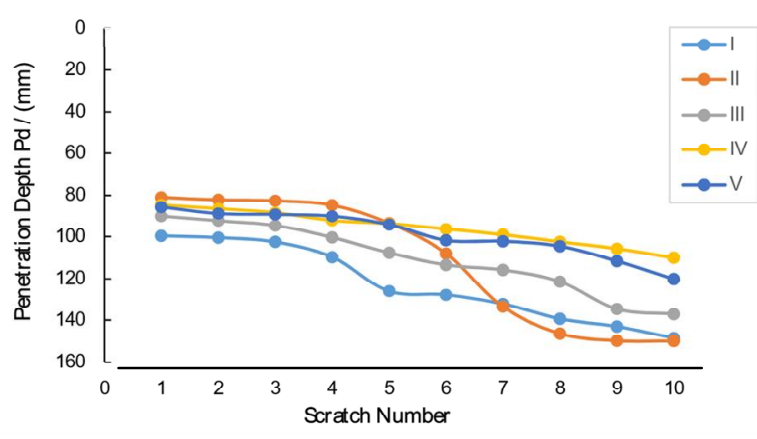

a)

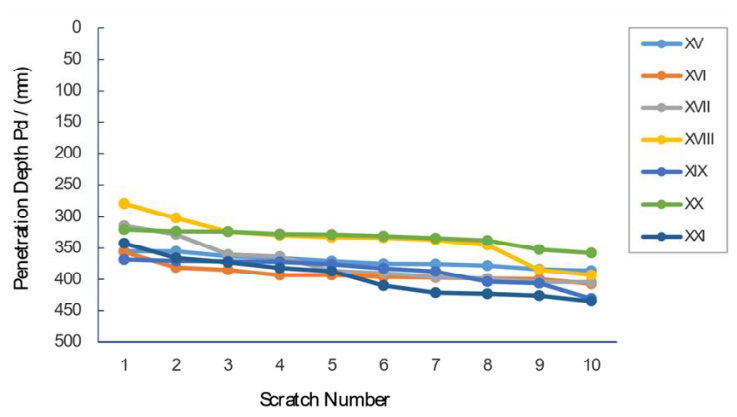

c)

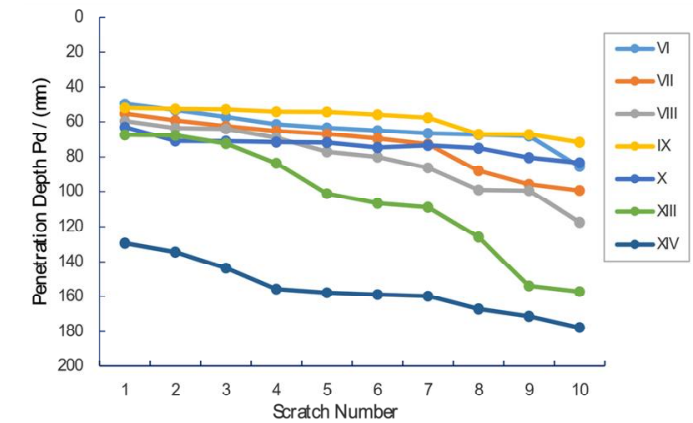

b)

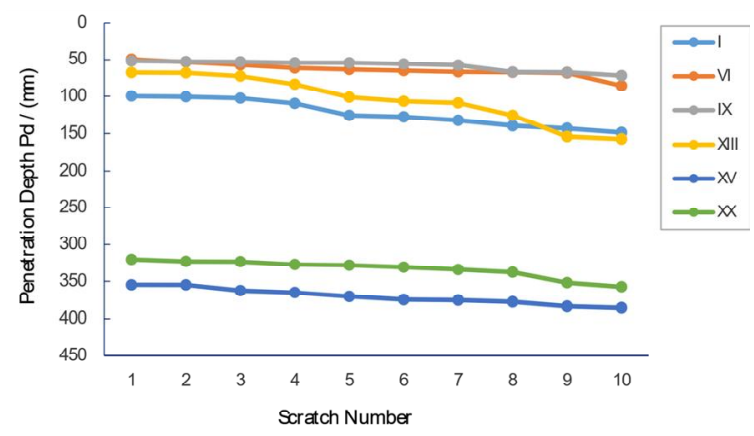

d)

Fig. 1. Penetration depths of polymeric matrices and hybrid composites based on them: hybrid composites containing $\mathrm{F}_{4} \mathrm{MA}$ $\operatorname{AGE}(1: 1 / 7: 3)(a, b)$; hybrid composites containing $F_{8}$ MA-AGE $(1: 1 / 7: 3)(c)$ and comparison of penetration depths for hybrid composites containing $\mathrm{F}_{4} \mathrm{MA}-\mathrm{AGE} \& \mathrm{~F}_{8} \mathrm{MA}-\mathrm{AGE}(1: 1 / 7: 3)$ (d)

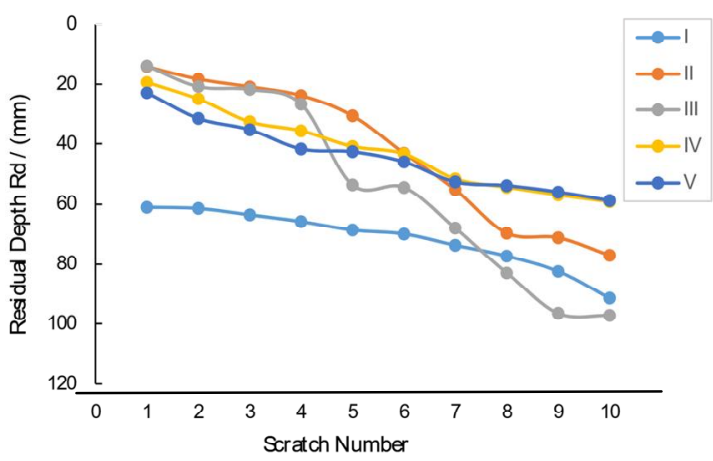

a)

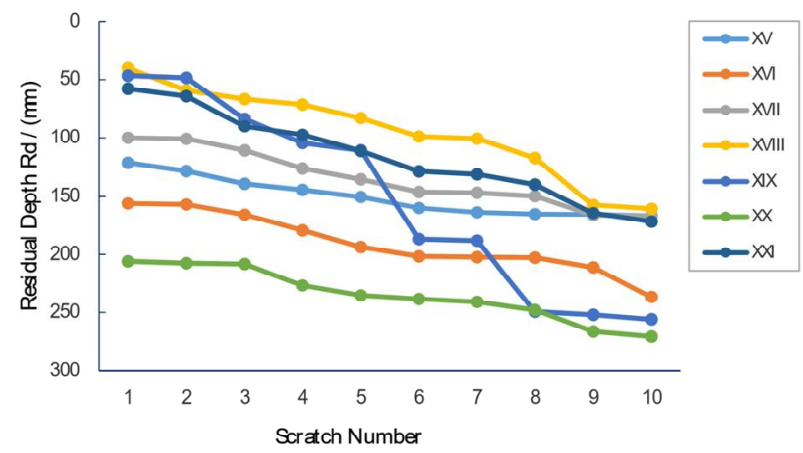

c)

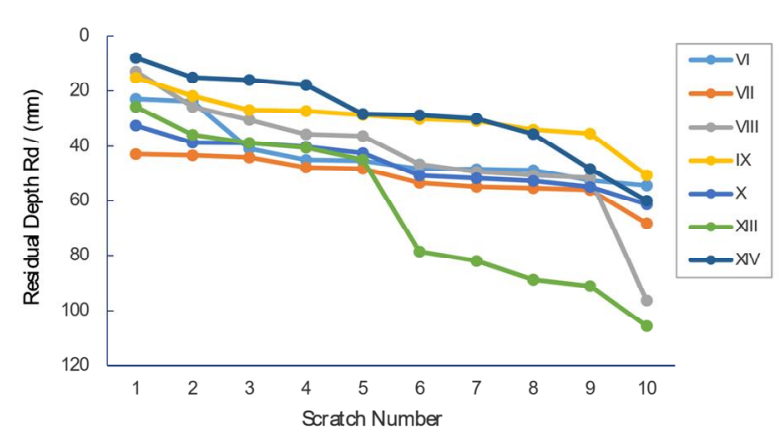

b)

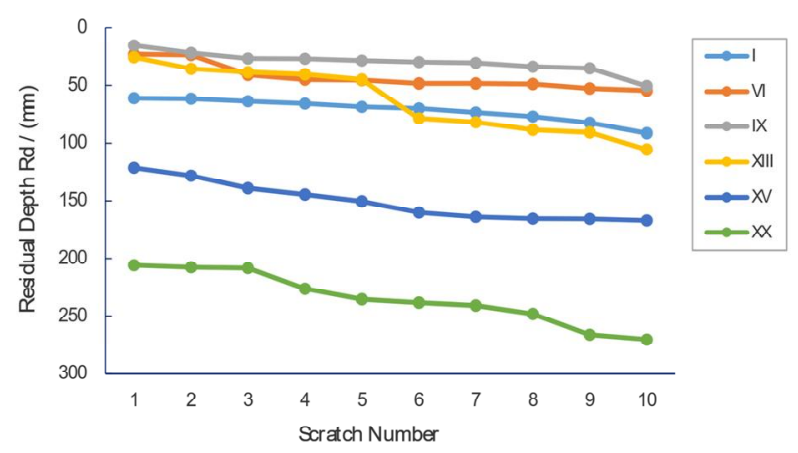

d)

Fig. 2. Residual depths of polymeric matrices and hybrid composites based on them: hybrid composites containing $\mathrm{F}_{4}$ MA-AGE $(1: 1 / 7: 3)(\mathrm{a}, \mathrm{b})$; hybrid composites containing $\mathrm{F}_{8} \mathrm{MA}-\mathrm{AGE}(1: 1 / 7: 3)(\mathrm{c})$ and comparison of penetration depths hybrid composites containing $\mathrm{F}_{4} \mathrm{MA}-\mathrm{AGE} \& \mathrm{~F}_{8} \mathrm{MA}-\mathrm{AGE}(1: 1 / 7: 3)$ (d) 
We see that modification with bioactive components provides lowering of the residual depth of hybrid composites based on 1,1,5-trihydrooctafluoropropyl methacrylate (Fig. 2; XVII, XVIII, XXI). Comparison of the results for polymer matrices containing fluoroalkyl and epoxy side groups ( $\left.\mathrm{F}_{4} \mathrm{MA}-\mathrm{AGE} \& \mathrm{~F}_{8} \mathrm{MA}-\mathrm{AGE}\right)$ shows a significant decrease of residual depths due to increasing concentration of the curing agent (Fig. 2; I, VI, IX). An increase of fluoroalkyl chain length of methacrylic copolymers, using polymer matrices with the same composition, causes a significant increase of $R_{h}$ values (Fig. 2; VI and XV, IX and XX, respectively). Among the tested matrices the shallowest $\mathrm{R}_{h}$ is seen for the polymer matrix $\mathrm{F}_{4} \mathrm{MA}-\mathrm{AGE}$ 1:1/10 wt. \% HMDA (Fig. 2; IX).

Significant improvement in viscoelastic recovery of modified hybrid materials is seen as well (Fig. 3). The values of $\varphi$ calculated from Eq. (1) are in the range between 53 and $97 \%$.

For composites obtained based on $\mathrm{F}_{4} \mathrm{MA}-\mathrm{AGE}$ (equimolar ratio) the viscoelastic recovery is reduced by increasing curing agent content from 5 to 7 and then to $10 \mathrm{wt} \%$ (Fig. 3; I, VI, IX). For the polymer composites with otherwise the same composition, the value of $\varphi$ is increased on the average by $30-40 \%$ along with increasing

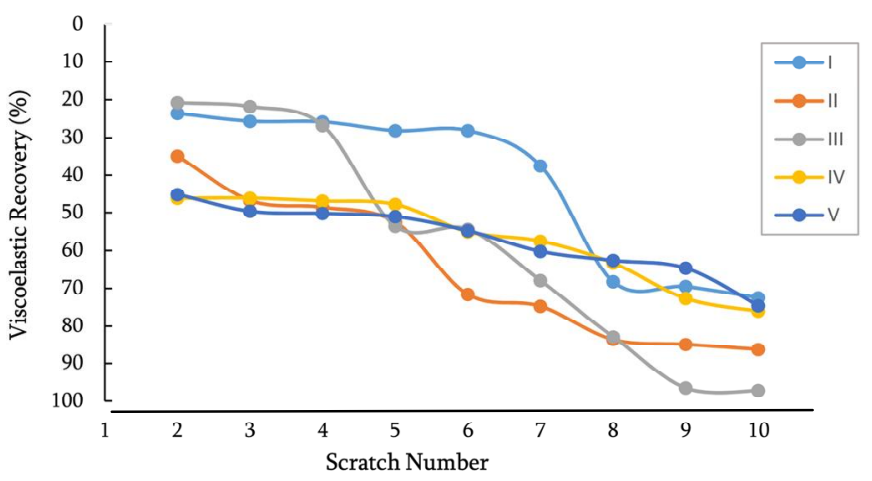

a)

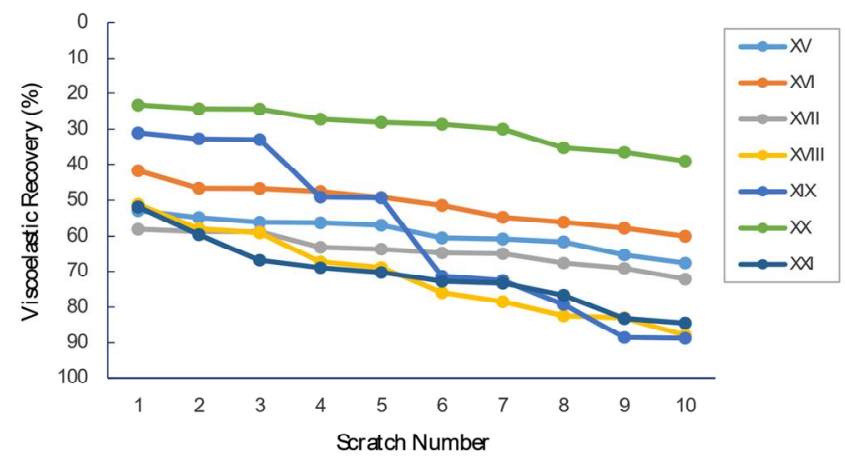

c) the molar ratio of fluoroalkyl methacrylic copolymers (Fig. 3; VI-VIII, XIV). For composites based on $\mathrm{F}_{8} \mathrm{MA}-$ AGE we see the higher viscoelastic recovery for composites with a lower content of curing agent (Fig. 3; $\mathrm{XV}, \mathrm{XX}$ ). Further modification with BCs improves the recovery behavior of scratched surfaces (Fig. 3; XVIIXIX, XXI).

Thus, viscoelastic recovery of our composites is significantly improved by increasing the fluoroalkyl chain length and molar ratio of corresponding methacrylic copolymers (Fig. 3; VI, XV). As expected, the scratch resistance and recovery are related to the local molecular structure, in particular to the intrachain bonds (primary interactions) of the segments on the scratching path.

We note that the sliding wear determination results were the basis for formulating an equation for the polymer brittleness $B[25,27]$, namely:

$$
B=1 /\left[\varepsilon_{b} \cdot E^{\prime}\right]
$$

where $\varepsilon_{\mathrm{b}}$ is the tensile elongation at break at a given temperature $T ; E$ ' is the storage modulus at the same temperature obtained by dynamic mechanical analysis (DMA, see [25]); $B$ for polymers is related to the viscoelastic recovery $\phi$ defined by Eq. (1), namely [27]:

$$
\phi=30.6+67.1 e^{-B / 0.505}
$$

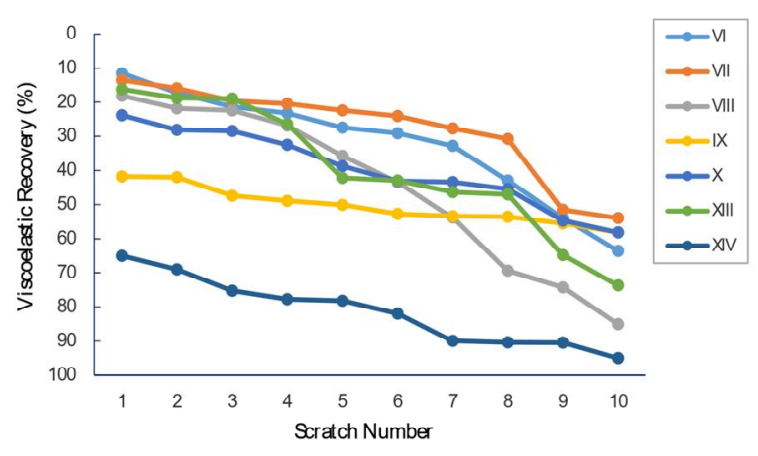

b)

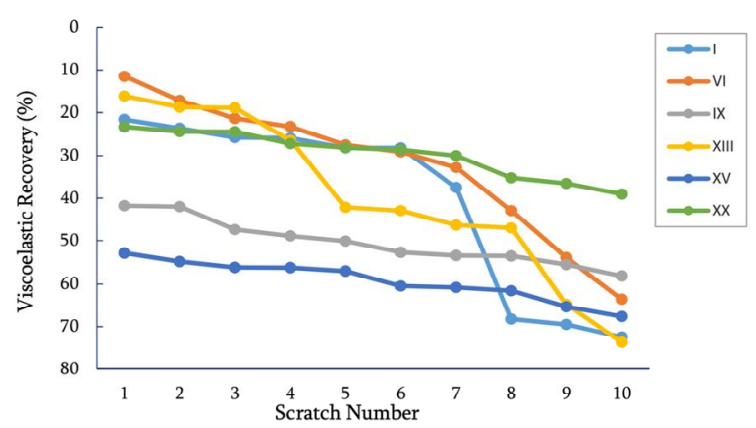

d)

Fig. 3. Viscoelastic recovery of polymer matrices and hybrid composites based on them: hybrid composites containing $F_{4} M A-A G E$ $(1: 1 / 7: 3)(a, b)$; hybrid composites containing $F_{8}$ MA-AGE (1:1 / 7:3) (c); and comparison of penetration depths for hybrid composites containing $\mathrm{F}_{4} \mathrm{MA}-\mathrm{AGE}$ and $\mathrm{F}_{8} \mathrm{MA}-\mathrm{AGE}(1: 1 / 7: 3)$ (d) 


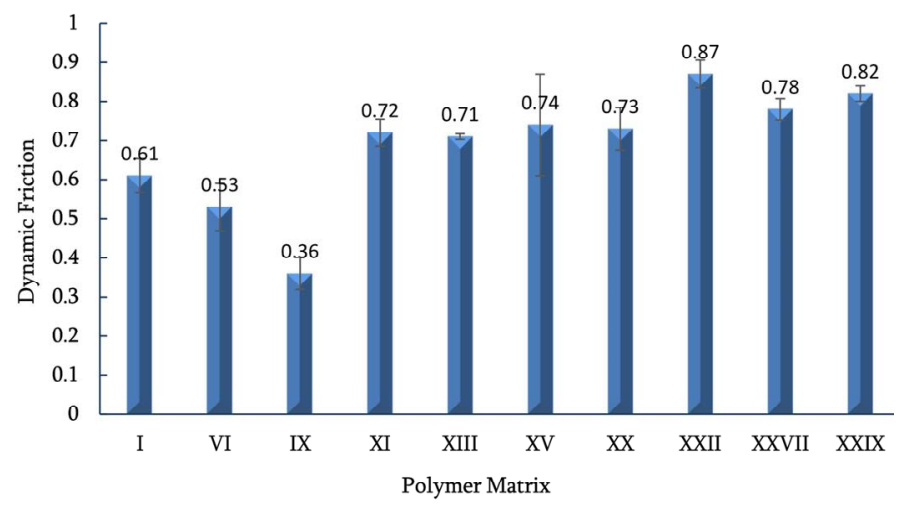

a)

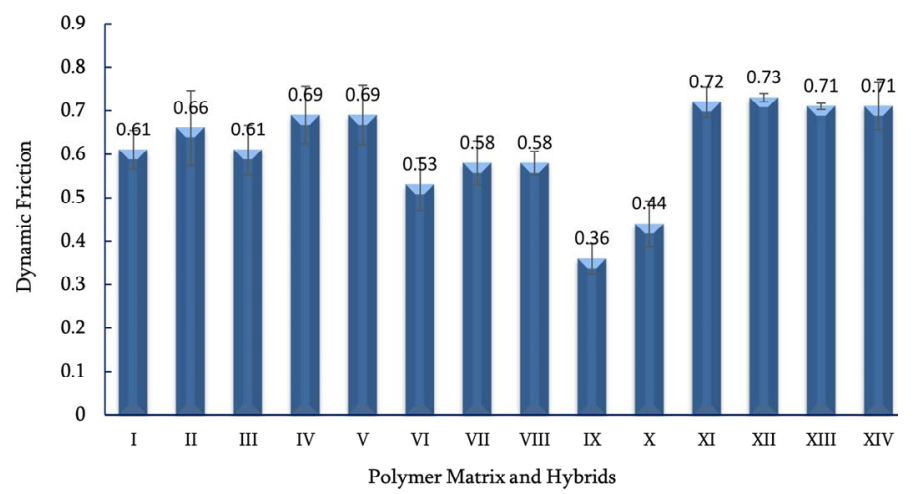

b)

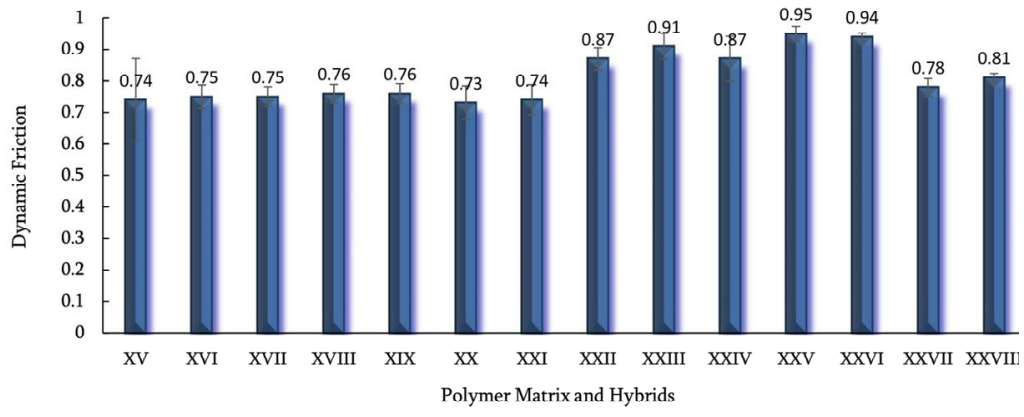

c)

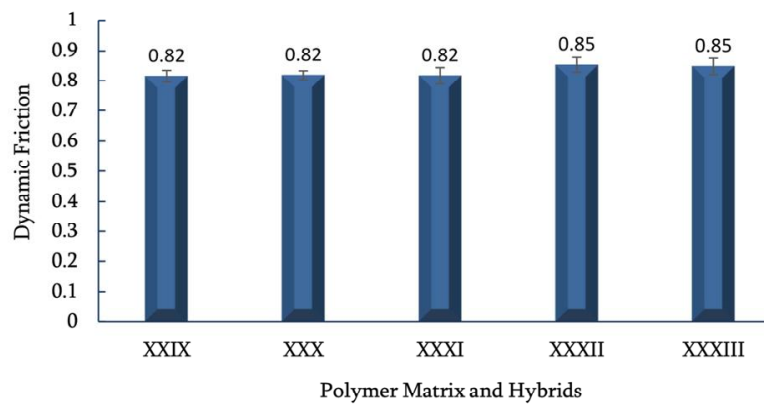

d)

Fig. 4. Dynamic friction values of polymer matrices containing perfluoroalkyl methacrylic and epoxy side groups and hybrid composites based on them: results for polymer matrices $\left(\mathrm{F}_{4} \mathrm{MA}-\mathrm{AGE}, \mathrm{F}_{8} \mathrm{MA}-\mathrm{AGE}\right.$ and $\left.\mathrm{F}_{12} \mathrm{MA}-\mathrm{AGE} ; 1: 1 / 7: 3\right)$ (a);

hybrid composites containing $\mathrm{F}_{4}$ MA-AGE (1:1/ 7:3) (b); hybrid composites containing F $\mathrm{F}_{8} \mathrm{MA}-\mathrm{AGE}(1: 1 / 7: 3)$ (c); and hybrid composites containing $\mathrm{F}_{12} \mathrm{MA}-\mathrm{AGE}(1: 1)$ (d) 


\subsection{Dynamic Friction Results}

Qualitatively, friction is defined as the resistance to relative motion between two bodies in contact [25]. Static friction pertains to starting the motion, dynamic to maintaining it at a constant velocity. In many cases, we are interested in low friction values; not always since high friction provides high ballistic penetration resistance. Fig. 4 shows selected results obtained.

Dynamic friction as a function of composition of tested hybrids largely decreases when increasing the curing agent content (Fig. 4; I/VI/IX; XXII/XXVII, respectively). Insignificant reduction of dynamic friction is observed for composites $\mathrm{XI} / \mathrm{XIII}$ and $\mathrm{XV} / \mathrm{XX}$. The increase of molar ratio of methacrylic copolymers causes substantial increase of the friction values for composites with similar compositions (Fig. 4; VI/XI; IX/XIII; $\mathrm{XV} / \mathrm{XXII}$; respectively). Meanwhile, the increase of fluoroalkyl chain length in the composites with similar compositions show the increase of the friction values of corresponding samples (Fig. 4; VI, XV and XXIX).

Comparison of average dynamic friction values of polymer composites based on $\mathrm{F}_{4} \mathrm{MA} / \mathrm{F}_{8} \mathrm{MA} / \mathrm{F}_{12} \mathrm{MA}-\mathrm{AGE}$ $(1: 1)$ and corresponding hybrids obtained by their further modification with BCs show insignificant increases (Fig. 4; XXIII-XXVI, XXVIII, XXX-XXXIII). The lowest dynamic friction is seen for the composite $\mathrm{F}_{8} \mathrm{MA}-\mathrm{AGE}$ 1:1/10 wt \% HMDA (Fig. 4; XX and XXI). Small changes of dynamic friction for hybrids with similar compositions are not important for the application; consider the methacrylic copolymer $\left(\mathrm{F}_{4} \mathrm{MA}-\mathrm{AGE}=7: 3\right)$ with either 7 or $10 \%$ HMDA (Fig. 4; XII and XIV).

Relatively high dynamic friction values are seen for the matrices based on the copolymer with the longest fluoroalkyl chain $\left(\mathrm{F}_{12} \mathrm{MA}\right)$. We recall here the Bump Model developed in [28]. In friction testing the pin (indenter) does not move continuously along the surface but rather jumps from bump to bump. Composite IX in Figure 4 shows the lowest friction value of all. Its composition is $\mathrm{F}_{4} \mathrm{MA}-\mathrm{AGE}$ 1:1/10 \% HMDA. Apparently HDMA provides small bumps. The highest value of $\lambda$ is seen for $\mathrm{F}_{8} \mathrm{MA}-\mathrm{AGE}$ 7:3/3\% BC-3/7\% HMDA. Two factors seem to contribute to that highest $\lambda$ value. First, as we see in Scheme 2, BC-3 has an unusually complicated three-dimensional structure, providing large obstacles to the indenter movement. Second, $\mathrm{F}_{8} \mathrm{MA}-\mathrm{AGE}$ has twice as long polymeric chain as $\mathrm{F}_{4} \mathrm{MA}-\mathrm{AGE}$, providing larger bumps. In $\mathrm{F}_{12} \mathrm{MA}-\mathrm{AGE}$ reversals of fluoroalkyl chain directions are possible, providing smaller obstacles to the indenter movement.

\subsection{Surface Morphology Observations}

SEM observations of surface microstructures of our composites after tribological tests are displayed in Fig. 5.
The wear tracks for hybrids based on equimolar ratio of copolymers $\left(\mathrm{F}_{4} \mathrm{MA} / \mathrm{F}_{8} \mathrm{MA}-\mathrm{AGE}\right)$ and $10 \mathrm{wt} \%$ of curing agent are insignificant (Fig. 5; X and XXI). The increase of molar ratio of copolymers makes the wear tracks slightly more visible when compared to the hybrids with equimolar content of copolymers (Fig. 5; X/XIV; $\mathrm{XXI}$ XXVIII, respectively). Composite XXVIII shows wear debris, and in optical image of the longest fluoroalkyl chain copolymer $\left(\mathrm{F}_{12} \mathrm{MA}\right)$ wear debris with crack formation is observed (Fig. 5; XXXII).

By comparison of surface microstructures of tested materials based on various copolymers having similar composition, better scratch and wear resistance is shown for the polymer composites and hybrids containing the shortest fluoroalkyl methacrylic chain copolymer $\left(\mathrm{F}_{4} \mathrm{MA}\right)$.

Thus, observations of surface microstructures are in agreement with our tribology results. Wear resistance is determined by the structure of used perfluoroalkyl methacrylates, by molar ratio of copolymers and by composition of targeted hybrid composites.

\subsection{Aging and Weatherability}

Aging tests at 313 and $333 \mathrm{~K}$ in the air were performed to determine weatherability (complex action of moisture, air oxygen, carbon dioxide, and visible light) of our hybrids. For six months all samples maintained their initial appearance, color, optical transparency and mechanical properties (surface homogeneity without splits formation).

Moisture medium affects the rate of microbial attachment and microbe dissemination on materials surfaces. Thus, hydrophobic properties of coatings play significant role in the process of adhesion of microorganisms on various surfaces.

The water absorption ability was determined by the gravimetric method described by Travinskaia and colleagues [29]. The water absorption $\Delta W$ can be calculated as:

$$
\Delta W=\left[\left(M_{S}-M_{D}\right) / M_{S}\right] \cdot 100 \%
$$

where $M_{S}$ is the mass of the material saturated with water; $M_{D}$ is the mass of the dry material.

We have found that the water absorption of our hybrid coatings determined after $720 \mathrm{~h}$ does not exceed $0.002-0.01 \mathrm{wt} \%$ in all cases. Thus, the dry experimental condition in tests is close to the real application conditions of our hydrophobic hybrids.

To provide first a broad perspective, Materials Science and Engineering involves crystal structures [30], metals - including their mechanics [31], phase diagrams [32] and corrosion [33], as well as materials for saving energy [34], and petroleum [35] which is the source of synthetic polymers. Basic classes of materials include petroleum and other organic raw materials, ceramics, polymers, and composites [26]. The importance of 
petroleum has been explained by Lucas and colleagues [35-39]. The role of polymers has been explained by Gedde and Hedenqvist [40].

Needless to say, there is a variety of polymers and a large variety of their applications. Engineering polymers include polypropylene [41], a variety of poly- ethylenes and poly(vinyl chloride). There are also polymers for specific uses. Thus, Taczała and colleagues developed poly(methyl methacrylate) reinforced with chemically modified cellulose microfibers for dental applications [42]. For reasons stated in the beginning, we focused on epoxies [43-50].

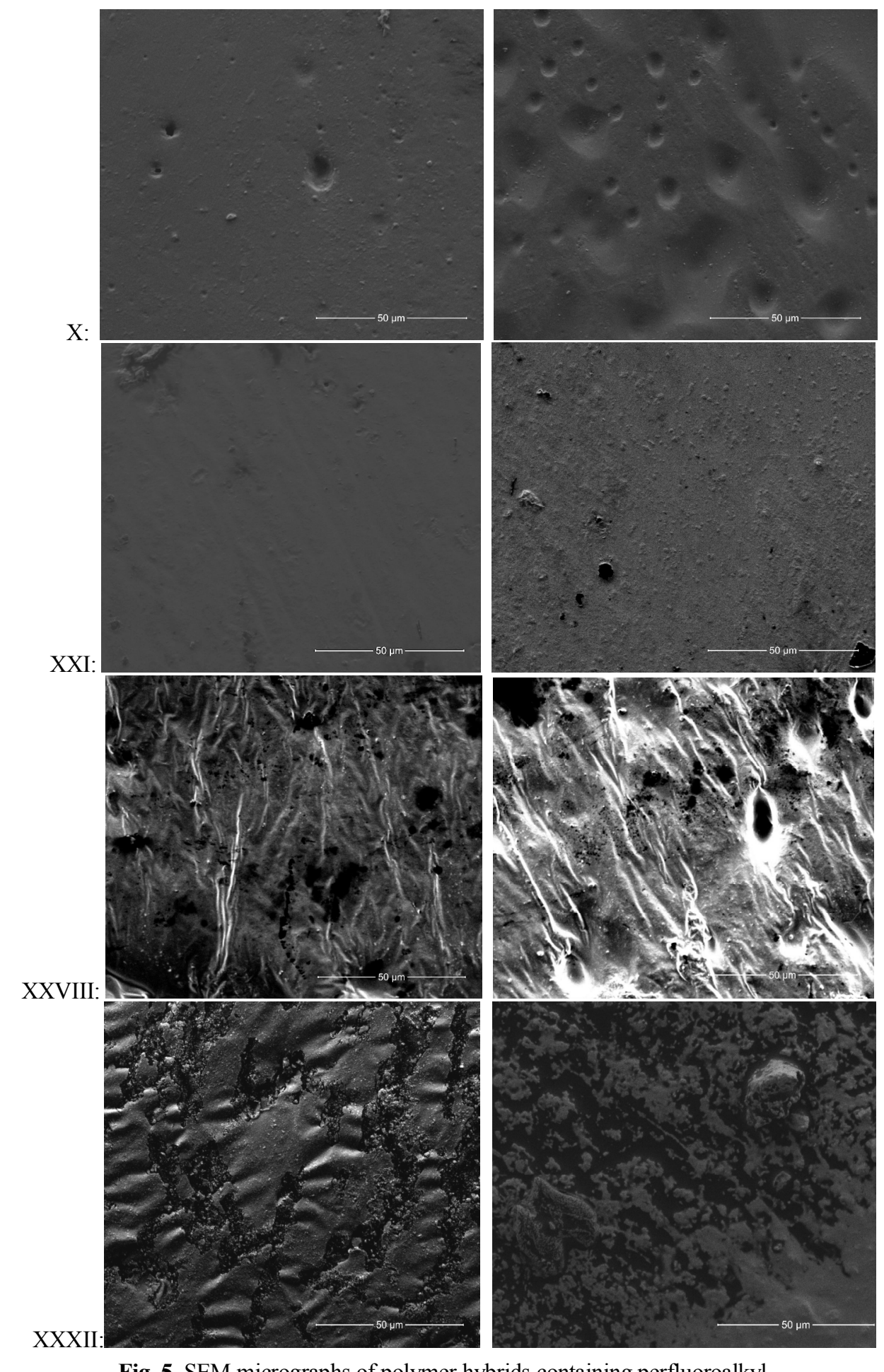

Fig. 5. SEM micrographs of polymer hybrids containing perfluoroalkyl methacrylic and epoxy side groups before and after tribology testing and thermal aging $(50 \mu \mathrm{m})$ 


\section{Conclusions}

In this work we have developed novel photostable, hydrophobic antimicrobial materials based on functionalized fluorine-organic methacrylate copolymers containing epoxy groups in the main chains. These materials have improved tribological characteristics: less wear, higher scratch resistance, appropriate viscosity, and acceptable dynamic friction. Our hybrids are characterized by high thermal stability and good adhesion to various substrates. They can be used for both short-term and longterm protection of cultural heritage and also as coatings for a variety of objects against a wide spectrum of biodestructors.

\section{Acknowledgements}

This work was supported by the Fulbright Foundation, Washington, DC, in the form of a Senior Scholarship to Khatuna Barbakadze for her stay at the University of North Texas.

\section{References}

[1] Sambhy V., MacBride M., Peterson B., Sen A.: J. Am. Chem. Soc., 2006, 128, 9798. https://doi.org/10.1021/ja061442z

[2] Preserving our Heritage, Improving our Environment, European Commission, DG Research, Information and Communication Unit, Brussels 2009.

[3] Gomez-Romero P., Sanchez C.: Functional Hybrid Materials, Wiley-VCH, Weinheim 2006.

[4] Chujo Y., KONA Powder Part. J., 2007, 25, 255.

https://doi.org/10.14356/kona.2007023

[5] Zvonkina I., Soucek M.: Curr. Opin. Chem. Eng., 2016, 11, 123. https://doi.org/10.1016/j.coche.2016.01.008

[6] Kenawy E., Worley S., Broughton R. Biomacromolecules, 2007, 8, 1359. https://doi.org/10.1021/bm061150q

[7] Mammadova N., Abbasov V., Mammadkhanova S., Ahmadbayova S. Proc. Petrochem. Oil Ref. 2018, 19, 180.

[8] Savelyev Yu.: Polyurethane Thermoplastic Elastomers Comprising Hydrazine Derivatives: Chemical Aspects [in:] Fakirov S. (Ed.), Handbook of Condensation Thermoplastic Elastomers, Wiley-VCH, Weinheim 2005, 355-380.

https://doi.org/10.1002/3527606610.ch13

[9] Vitale A., Bongiovanni R., Ameduri B.: Chem. Rev., 2015, 115, 8835. https://doi.org/10.1021/acs.chemrev.5b00120

[10] Teng H.: Appl. Sci., 2012, 2, 496.

https://doi.org/10.3390/app2020496

[11] Kostov G., Ameduri B., Boutevin B.: J. Fluor. Chem., 2002,

114, 171. https://doi.org/10.1016/S0022-1139(02)00023-4

[12] Lekishvili N., Lachinov M., Zaikov G.: Fluorine-containing Polymers for Materials with the Complete Internal Light-reflection (Review) [in:] Pethrick R, Zaikov G. (Eds.) Polymer Yearbook. Rapra technology 2003, 209-250.

[13] Erol I., Arslanturk B., Gurler Z.: Polym. Sci. B, 2015, 3, 228 https://doi.org/10.1134/S1560090415030045
[14] Smith Jr. D., Iacono S., Boday D., Kettwick S. (Eds.): Advances in Fluorine-Containing Polymers. ACS Symposium Series Vol. 1106, 2013.

[15] Mukbaniani O., Brostow W., Aneli J. et al.: Mater. Technol., 2020, 54, 33. https://doi.org/10.17222/mit.2019.091

[16] Yao W., Li Y., Huang X.: Polymer, 2014, 55, 6197. https://doi.org/10.1016/j.polymer.2014.09.036

[17] Lekishvili N., Nadareishvili L., Zaikov G., Khananashvili L.: Polymers and Polymeric Materials for Fiber and Gradient Optics. VSP (International Science Publishers), Utrecht-Boston-KölnTokyo 2002.

[18] Barbakadze Kh., Brostow W., Datashvili T. et al.: Wear, 2018, 394-395, 228. https://doi.org/10.1016/j.wear.2017.08.006

[19] Barbakadze Kh., Brostow W., Hnatchuk N. et al.: Mater. Res. Innovat., 2015, 19, 227.

https://doi.org/10.1179/1433075X14Y.0000000256

[20] Lachinov M., Guliashvili T., Lekishvili N., Khananashvili L.: Polym. Sci. A, 1998, 40, 88.

[21] Lekishvili N., Barbakadze Kh., Zurabishvili D. et al.: Oxid. Commun., 2010, 33, 104.

[22] Sadym A., Lagunin A., Filimonov D., Poroikov V.: Chem. Pharm. J., 2002, 36, 21. https://doi.org/10.1023/A:1022402425883 [23] Menard K.P.: Ch. 6 [in:] Brostow W.(Ed.), Performance of Plastics. Hanser, Munich - Cincinnati 2000.

[24] Khedkar J., Negulescu I., Meletis E.: Wear, 2002, 252, 361. https://doi.org/10.1016/S0043-1648(01)00859-6

[25] Brostow W., Hagg Lobland H.: Materials: Introduction and Applications, John Wiley \& Sons, 2017.

[26] Kalogeras I., Hagg Lobland H.: J. Mater. Educ., 2012, 34, 69. [27] Brostow W., Hagg Lobland H., Narkis M.: J. Mater. Res., 2006, 21, 2422. https://doi.org/10.1557/jmr.2006.0300

[28] Brostow W., Kumar P., Vrsaljko D., Whitworth J.: J. Nanosci. Nanotech., 2011, 11, 3922. https://doi.org/10.1166/jnn.2011.3849

[29] Travinskaia T., Mishuk E., Perepelitisina L., Savyelyev Yu.: Polimernyi Zh., 2010, 32, 66.

[30] Bardella F., Montes Rodrigues A., Leal Neto R., Crystalwalk: J. Mater. Educ., 2019, 41, 157.

[31] Zhang Y.: J. Mater. Educ., 2019, 41, 51.

[32] Krzywicka M., Grudzinski J., Czarnacka K.: J. Mater. Educ., 2020, 42, 245.

[33] Çomez N., Gül C., Durmus H., Sadrettin Zeybec M.: J. Mater. Educ., 2020, 42, 235.

[34] Fedotov A., Drozdov N., Mazanik A. et al.: J. Mater. Educ., 2007, 29, 35.

[35] Middea A., Monte M., Lucas E.: Chem. Chem. Technol., 2008, 2, 91. https://doi.org/10.23939/chcht02.02.091

[36] Garretto M., Gonzalez G., Ramos A., Lucas E.: Chem. Chem. Technol., 2010, 4, 317. https://doi.org/10.23939/chcht04.04.317

[37] Spinelli L., Lucas E.: J. Mater. Educ., 2017, 39, 125.

[38] Vianna E., Figuiredo V., Middea A. et al.: J. Mater. Educ., 2019, 41, 41.

[39] Guerrero-Martin C., Montes-Paéz E., Lucas E.: J. Mater. Educ., 2019, 41, 189.

[40] Gedde U., Hedenqvist M.: Fundamental Polymer Science, $2^{\text {nd }}$ edn. Springer Nature, Switzerland 2019.

https://doi.org/10.1007/978-3-030-29794-7

[41] Grebowicz J., Lau S.-F., Wunderlich B.: J. Polym. Sci., 1984, 71, 19. https://doi.org/10.1002/polc.5070710106

[42] Taczała J., Sawicki J., Pietrasik J.: Materials, 2020, 13, 3807. https://doi.org/10.3390/ma13173807

[43] Bilyeu B., Brostow W., Menard K.P.: J. Mater. Educ., 1999, 21, 281. 
[44] Bilyeu B., Brostow W., Menard K.P.: J. Mater. Educ., 2000, 22, 107.

[45] Bilyeu B., Brostow W., Menard K.P.: J. Mater. Educ., 2001, 23, 189

[46] Bilyeu B., Brostow W., Menard K.P.: Polym. Compos., 2002, 23, 1111. https://doi.org/10.1002/pc. 10505

[47] Iatsyshyn O., Astakhova O., Shyshchak O. et al.: Chem. Chem. Technol., 2013, 7, 73. https://doi.org/10.23939/chcht07.01.073

[48] Bratychak M., Astakhova O., Shyshchak O. et al., Chem. Chem. Technol., 2019, 13, 360.

https://doi.org/10.23939/chcht13.03.360

[49] Bratychak M., Astakhova O., Shyshchak O. et al.: Chem.

Chem. Technol., 2020, 14, 343.

https://doi.org/10.23939/chcht14.03.343

[50] Bratychak M., Astakhova O., Shyshchak O.: Chem. Chem.

Technol., 2020, 14, 504. https://doi.org/10.23939/chcht14.04.504

Received: May 03, 2021 / Revised: July 03, 2021 / Accepted: September 02, 2021

\section{АНТИБІОКОРОЗИВНІ ГІБРИДНІ МАТЕРІАЛИ ПІДВИЩЕНОЇ МІЦНОСТІ}

Анотація. Одержані нові антикорозійні багатофункціональні гібридні матеріали на основі функиійних перфторалкілметакрилатних кополімерів з епоксидними групами в основних ланцюгах та окремих біологічно активних сполук. Визначено, щзо гібриди є прозорими, демонструють непогану адгезію до різних поверхонь (пластик, дерево), високу в'язкоеластичну рекуперацію при випробуванні на подряпини, низькі показники зносу та температуру склування понад 323 К. За допомогою скануючої електронної мікрографї встановлено, щчо поділу фаз не відбувається. Підвищена механічна міцність $і$ непогана стійкість до стирання є перевагами для використання синтезованих захисних та антикорозійних покриттів у різних сферах застосування, включаючи охорону культурної спадщчин.

Ключові слова: гібридні матеріали, захисні покриття, антикорозійні покриття, перфторалкілметакрилати. 